\title{
Feeding and growth by ephyrae of scyphomedusae Chrysaora quinquecirrha
}

\author{
Niels Jørn Olesen ${ }^{1, *}$, Jennifer E. Purcell ${ }^{2}$, Diane K. Stoecker ${ }^{2}$ \\ ${ }^{1}$ National Environmental Research Institute, Vejlsøvej 25, PO Box 314, DK-8600 Sílkeborg, Denmark \\ ${ }^{2}$ University of Maryland System, Center for Environmental and Estuarine Research, Horn Point Environmental Laboratory, \\ PO Box 775, Cambridge, Maryland 21613, USA
}

\begin{abstract}
Clearance rates of Chrysaora quinquecirrha ephyrae were quantified in the laboratory using monocultures of different plankton organisms as prey, as well as mixed natural zooplankton assemblages. Further, growth of ephyrae was measured at different densitjes of rotifers or ctenophores as prey. The ciliate Strobilidium sp. (strain CRE) and the rotifer Brachionus plicatilis were cleared in monocultures at medium rates: $4 \mathrm{ml} \mathrm{h}^{-1}$ ind.-1 and $1 \mathrm{ml} \mathrm{h}^{-1}$ ind ${ }^{-1}$ respectively. Clearance of copepod nauplii was low $\left(0.5 \mathrm{ml} \mathrm{h}^{-1}\right.$ ind $\left.{ }^{-1}\right)$ and the dinoflagellates Gymnodinium sanguineum were not eaten by the ephyrae. In a mixed zooplankton assemblage, rotifers and copepod nauplii were cleared at rates similar to those obtained in monocultures, and tintinnids also were eaten. In contrast, larvae of the ctenophore Mnemiopsis leidyi were cleared at a much higher rate $\left(30 \mathrm{ml} \mathrm{h}^{-1}\right.$ ind.-1) than microzooplankton. When the rotifer B. plicatilis were offered in excess to ephyrae, a maximum specific growth rate of $0.3 \mathrm{~d}^{-1}$ was measured. Growth rate more than doubled $\left(0.7 \mathrm{~d}^{-1}\right)$ when ctenophore larvae were offered. The growth rate obtained on ctenophore larvae is the highest rate reported so far for any scyphomedusan species. We suggest that $M$. leidyi may be of critical importance for the high growth of C. quinquecirrha ephyrae in natural populations during springtime in Chesapeake Bay, USA.
\end{abstract}

KEY WORDS: Scyphomedusae Chrysaora quinquecirsha Ctenophore Predation Growth

\section{INTRODUCTION}

Scyphomedusae are large conspicuous predators of zooplankton in many coastal areas. The sea nettle Chrysaora quinquecirrha is found from the southern coast of New England (USA) to the tropics along the east coast of North America (Mayer 1910). In the mesohaline region of Chesapeake Bay (USA), C. quinquecirrha becomes extremely abundant in late spring and summer (Purcell 1992, Purcell et al. 1994a, b) and negatively affects aquatic recreational activities there. Observed changes in the plankton community (Feigenbaum \& Kelly 1984), a model of Chesapeake Bay food webs (Baird \& Ulanowicz 1989), and recent trophic studies (Purcell 1992, Purcell et al. 1994a, b) all suggest that $C$. quinquecirrha medusae are important in the plankton dynamics of the bay.

•E-mail: fvnjo@wpgate.dmu.dk
Most previous studies of this species have been done on the benthic polyp stage (e.g. Cargo \& Schultz 1966, 1967. Cones 1969, Loeb 1972, Loeb \& Blanquet 1973 , Cargo \& Rabenold 1980), or on the abundance and feeding ecology of the medusa stage (Clifford \& Cargo 1978, Feigenbaum \& Kelly 1984, Cargo \& King 1990 , Purcell 1992). The adult medusa of Chrysaora quinquecirrha is known to feed on a wide variety of zooplankton, with copepods, ichthyoplankton and ctenophores being key components of the diet (Purcell 1992, Purcell et al. 1994a, b).

Ephyrae of Chrysaora quinquecirrha are budded from the polyps in spring when water temperatures rise above $17^{\circ} \mathrm{C}$. There is little information on feeding of the ephyrae of any jellyfish species. Purcell (1992) summarizes data from Haven \& Morales-Almo (1973)

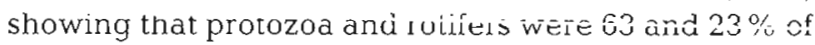
the prey caught by ephyrae of $C$. quinquecirrha in natural water samples. 
Similarly, very few measurements exist on growth rates of ephyrae of jellyfish species. Olesen et al. (1994) measured that ephyrae of Aurelia aurita attained a maximum growth rate of $0.3 \mathrm{~d}^{-1}$, when feeding on the rotifer Brachionus plicatilis in the laboratory. This value was close to the maximum values reported for field populations of $A$. aurita (Hernroth \& Groendahl 1983, Van der Veer \& Oorthuysen 1985), and 3 times higher than the maximum growth rate of a food limited natural population in the shallow fjord Kertinge Nor, Denmark (Olesen et al. 1994). In contrast, when Chrysaora quinquecirrha ephyrae were fed Artemia salina larvae, polychaetous annelids, or strained ctenophores in the laboratory, growth rates were low compared to apparent rates in situ (Cargo \& Schultz 1966. 1967).

This paper reports on the feeding rates of Chrysara quinquecirrha ephyrae on a variety of zooplankton organisms, offered in monocultures and in mixed zooplankton assemblages. Growth rates of ephyrae feeding on rotifers and on ctenophores are compared, and the relative importance of the different zooplankton organisms as food sources for the ephyrae of $C$. quinquecirrha are discussed.

\section{MATERIALS AND METHODS}

Production of ephyrae. Ephyrae of Chrysaora quinquecirrha for experimental purposes were raised in the laboratory. Oyster shells bearing sessile stages (cysts and polyps) of $C$. quinquecirrha were collected from Broad Creek, a tributary of Chesapeake Bay, in March 1993 and kept in estuary water $(12 \% \mathrm{~S})$ at $14^{\circ} \mathrm{C}$. Water was changed and the polyps were fed twice a week with newly hatched Artemia salina nauplii. Excystment and strobilation were initiated by raising the temperature to $21^{\circ} \mathrm{C}$. The ephyrae used in experiments were from 3 to $10 \mathrm{~d}$ old and 1 to $4 \mathrm{~mm}$ in diameter.

Clearance rates of microplankton in monoculture. Five different prey types were used to estimate clearance rates of Chrysara quinquecirrha: a dinoflagellate, Gymnodinium sanguineum (50 $\mu \mathrm{m})$, a ciliate, Strobilidium sp. (35 to $40 \mu \mathrm{m}$ ), and a rotifer, Brachionus plicatilis $(200 \mu \mathrm{m})$, which were cultured in the laboratory, and copepod nauplii (150 to $300 \mu \mathrm{m}$ ) and ctenophores Mnemiopsis leidyi (1 to $2 \mathrm{~mm}$ larvae), which were collected in a zooplankton net from the Choptank River tributary of Chesapeake Bay. The dinoflagellate G. sanguineum, a common species in Chesapeake Bay (Bockstahler \& Coats 1993), was cultured in the medium f/2 minus silica (Guillard 1975) made with estuarine water $(12$ to $15 \%)$ at $20^{\circ} \mathrm{C}$ on a $14: 10 \mathrm{~h}$ light:dark cycle. The ciliate Strobilidium sp. (strain CRE) was isolated from Choptank River, and grown under the same temperature and light conditions in estuarine water amended with $0.1 \mathrm{ml} \mathrm{l}^{-1}$ of $\mathrm{f} / 2$ ironEDTA trace metal solution with algae (Isochrysis galbana and Heterocapsa triquetral added as prey.

From 2 to 15 ephyrae were incubated for 8 to $24 \mathrm{~h}$ in 0.5 or 1.01 polycarbonate bottles with filtered $(20 \mu \mathrm{m})$ estuary water $(12 \%$ S). Prey was added from a stock solution. The prey density of this stock solution was determined after settling of subsamples as described by Hasle (1978). An inverted microscope was used for counting. Ten or 12 bottles were used in each experiment, and the decrease in prey organisms as a function of time were followed by processing 2 to 6 bottles at appropriate intervals. When copepod nauplii and rotifers were used as prey, water was filtered through a $20 \mu \mathrm{m}$ plankton gauze. The retained prey organisms were preserved in 5\% Bouins solution, and later counted by using a dissecting microscope. When ctenophores were used as prey, they were counted live at the end of the incubation. When ciliates or dinoflagellates were used as prey, we stopped the incubation by adding $30 \mathrm{ml}$ of $100 \%$ Bouins solution directly into the experimental bottle, after which subsamples i $100 \mathrm{mi}$ for dinoflagellates and $25 \mathrm{ml}$ for ciliates) were taken with a Hensen stempel pipette. These subsamples were then settled and counted as described above.

The incubation periods were 8 to $24 \mathrm{~h}$. At the end of each experiment, ephyrae were placed with the subumbrellar side down, and the interradial diameter was measured. Further, a subsample of 30 ephyrae from each experiment was examined in order to measure the average number of prey present in the gut of each individual by the end of the incubation. From 2 to 4 bottles in each experiment served as controls (without ephyrae). The experimental conditions are summarized in Table 1.

Clearance $(C)$ was calculated from the equation:

$$
C=[V /(\mathrm{n} \cdot t)] \ln \left(C_{0} / C_{l}\right)
$$

where $V$ is volume of the experimental bottle $(\mathrm{ml})$ $\mathrm{n}$ is number of ephyrae; $t=$ incubation time $(h)_{;} C_{0}$ and $C_{t}$ are number of prey organisms at times 0 and $t_{1}$ respectively.

All bottles were incubated in dim light and a test experiment revealed that there was no aggregation of prey items: when bottles were rotated on a plankton wheel (1 rpm) this did not affect the outcome of the experiments.

Clearance on mixed zooplankton. The clearance by Chrysaora quinquecirrha ephyrae of natural microzooplankton in mixed assemblage was also estimated. Microzooplankton was collected from the Choptank River in August 1993. Twelve liters of estuary water was back-filtered $(20 \mu \mathrm{m})$ to concentrate plankton organisms in order to obtain an adequate number at 
Table 1. Chrysaora quinquecirrha. Experimental conditions during clearance measurements using monoculture microplankton organisms. Salinity was $12 \%$

\begin{tabular}{|lccccccc|}
\hline Prey & $\begin{array}{c}\text { Temp } \\
\left({ }^{\circ} \mathrm{C}\right)\end{array}$ & $\begin{array}{c}\text { Container } \\
\text { volume } \\
(\mathrm{ml})\end{array}$ & $\begin{array}{c}\text { Incubation } \\
\text { period } \\
(\mathrm{h})\end{array}$ & $\begin{array}{c}\text { Number of } \\
\text { ephyrae }\end{array}$ & $\begin{array}{c}\text { Ephyrae } \\
\text { diameter } \\
(\mathrm{mm} \pm \mathrm{SD})\end{array}$ & $\begin{array}{c}\text { Prey } \\
\text { density } \\
\left(\mathrm{ind} . \mathrm{ml}^{-1}\right)\end{array}$ & $\begin{array}{c}\text { Prey } \\
\text { size } \\
(\mathrm{mm} \pm \mathrm{SD})\end{array}$ \\
\hline Gymnodinium sanguineum & 24 & 500 & 8 & 15 & $1.92 \pm 0.38$ & 40 & 0.05 \\
Strobilidium sp. (strain CRE) & 23 & 500 & 8 & 15 & $2.05 \pm 0.42$ & 8.8 & 0.035 \\
Brachionus plicatilis & 23 & 500 & 8 & 15 & $1.77 \pm 0.45$ & 2 & 0.2 \\
Copepod nauplii & 24 & 500 & 23 & 10 & $1.74 \pm 0.54$ & 0.2 & $0.15-0.3$ \\
Ctenophore (1) & 23 & 500 & 12 & 2 & $3.27 \pm 0.51$ & 0.04 & $1.5 \pm 0.4$ \\
Ctenophore (2) & 23 & 1000 & 24 & 2 & $3.60 \pm 0.57$ & 0.02 & $1.6 \pm 0.4$ \\
Ctenophore (3) & 23 & 1000 & 24 & 2 & $2.80 \pm 0.44$ & 0.01 & $1.6 \pm 0.4$ \\
\hline
\end{tabular}

the start of the experiment. The concentrate was added to $6 \mathrm{l}$ of unfiltered water from Choptank river (12\% S). The 4 dominant types of microzooplankton were identified and counted: aloricate ciliates, tintinnids, copepod nauplii and rotifers.

Fourteen incubation polycarbonate bottles (0.5 l) were filled with the microplankton sample, and kept in dim light at $24^{\circ} \mathrm{C}$. Thirty $\mathrm{ml}$ of $100 \%$ Bouins was then added to 4 of the 14 bottles, and two $20 \mathrm{ml}$ subsamples were taken from each bottle. These subsamples were then settled and counted as above to determine initial densities. Of the remaining 10 bottles, 20 ephyrae were added to each of 6 bottles (experimental bottles), and the last 4 bottles served as controls without ephyrae (control bottles). After 12 h, 2 of the experimental bottles were stopped by adding $30 \mathrm{ml}$ of $100 \%$ Bouins and 10 ephyrae from each were examined using a dissecting microscope in order to count the average number of prey present in the gut of each individual. After $24 \mathrm{~h}$, the remaining 4 experimental bottles and the 4 control bottles were stopped by adding $30 \mathrm{ml} 100 \%$ Bouins. Two $20 \mathrm{ml}$ subsamples were finally taken from each of the experimental and control bottles in order to count the final number of prey organisms. Before Bouins was added to 2 experimental bottles, 20 ephyrae from each were isolated and the umbrella diameter was measured as previously described. The experiment was initiated within $2 \mathrm{~h}$ of when the water sample was collected. Clearance was calculated according to Eq. (1), where $C_{0}=$ total number of prey at $t=0$ and $C_{t}=C_{0}$ - (total number of prey in control bottles at $t=24$ - total number of prey in experimental bottles at $t=24$ ).

Gut contents of ephyrae sampled in Chesapeake Bay. Thirty ephyrae were collected in tributaries of Chesapeake Bay for analyses of their gut contents. Four stations (the Tred Avon River, Broad Creek, and 2 stations in the Choptank River) were sampled every second week from 21 May to 25 August. Ephyrae were collected in surface tows of a $0.75 \mathrm{~m}$ diameter plankton net (333 $\mu \mathrm{m}$ mesh size) with a $0.5 \mathrm{l}$ cod end. The live samples were resuspended in a 201 bucket with estuary water, and the ephyrae removed individually. The ephyrae were carefully rinsed in $20 \mu \mathrm{m}$ filtered water $(12 \%$ S), and then preserved in $5 \%$ Bouins for later analysis using a dissecting microscope.

Growth rates of ephyrae. Growth of ephyrae was measured in 3 separate experiments using 31 plastic buckets. In Expt 1, 5 buckets with different densities of rotifers (94 to 1500 ind. $\mathrm{l}^{-1}$ ) and $20 \mu \mathrm{m}$ filtered estuary water were used. In Expt 2, ctenophore larvae Mnemiopsis leidyi were added to each of 6 buckets at densities of 0.3 to 23 ind. $\mathrm{l}^{-1}$, and in Expt 3, both rotifers and ctenophores were added at densities of 94 to 1500 rotifers $\mathrm{l}^{-1}$ and 3 to 50 ctenophores $\mathrm{l}^{-1}$.

In all 3 experiments, the incubation period was $4 \mathrm{~d}$. The ephyrae were transferred daily to new water with new prey organisms at the same initial density. After each $24 \mathrm{~h}$ period, the water in each bucket was filtered through a $20 \mu \mathrm{m}$ plankton gauze and the retained prey organisms were preserved in $5 \%$ Bouins solution to be counted later by using a dissecting microscope.

A control for Expt 3 was conducted in order to test if rotifers were eaten by the ctenophores. Three buckets with rotifers Brachionus plicatilis (750 ind. $\mathrm{l}^{-1}$ ) were incubated for $24 \mathrm{~h}$ together with ctenophore larvae (10 ind. $^{-1}$ ). The numbers of rotifers were unchanged by the end of the incubation period.

Clearance $(C)$ was calculated according to Eq. (1), and the instantaneous specific growth rate $(\mu)$, ingestion $(I)$, production $(P)$ and net growth efficiency (NGE) calculated according to the following equations:

$$
\begin{gathered}
\mu=\ln \left(W_{t} / W_{0}\right) \cdot t^{-1} \\
I=\left(C_{0}-C_{t}\right) / n \\
P=B_{0}-B_{i} \\
\text { NGE }=P / A=P / I \cdot A_{\text {eft }}
\end{gathered}
$$

where $W_{0}$ and $W_{t}$ are mean dry weight (mg) of ephyrae at time 0 and time $t$ respectively; $t$ is incubation time (h) $C_{0}$ and $C_{t}$ are numbers of prey uryanisnls at tiñe 0 and time $t_{i} \mathrm{n}$ is number of ephyrae; $B_{0}$ and $B_{t}$ are the mean carbon content of medusae at time 0 and time $t$ 
Table 2. Biometric conversions. C: carbon (mg); DW: dry weight $(\mathrm{mg})$; Diam: live diameter $(\mathrm{mm})$; L: live length $(\mathrm{mm})$

\begin{tabular}{|ll|}
\hline Chrysaora quinquecirrha & \\
$\mathrm{DW}=0.0021 \mathrm{Diam}^{2.886}, \mathrm{r}^{2}=0.94$ & (Purcell 1992) \\
$\mathrm{C}=0.000215 \mathrm{Diam}^{2003}, \mathrm{r}^{2}=0.92$ & (Purcell 1992) \\
Assimilation efficiency $=90 \%$ & (Purcell 1992) \\
(size range $14-100 \mathrm{~mm}$ diam) & \\
Mnemiopsis leidyi & \\
$\mathrm{DW}=0.0033 \mathrm{~L}^{20045}, \mathrm{r}^{2}=0.82, \mathrm{n}=40$ & (This study) \\
(size range $1-1.3 \mathrm{~mm}$ ) & (This study) \\
C/DW $=0.088=0.007, \mathrm{n}=30$ & \\
(size range $2-12 \mathrm{~mm}$ ) & \\
Brachionus plicatilis & (Szyper 1989) \\
C/ind. $=1.5 \times 10^{-4}$ &
\end{tabular}

respectively; $A$ is assimilation; and $A_{\text {eff }}$ is the assimilation efficiency. The biometric conversions factors and the assimilation efficienry used in the calculations arc given in Table 2.

Biometric conversion factors for ctenophores. In order to calculate net growth efficiency (NGE), the relationship between ctenophore length and dry weight was established; 40 ctenophore larvae were allowed to empty their guts, and the length of each individual ( 1 to $13 \mathrm{~mm}$ ) was then measured with an optical micrometer on a dissecting microscope. The ctenophores were then dried to constant weight in preweighed aluminium pans at $60^{\circ} \mathrm{C}$ and finally weighed to the nearest $1 \mu \mathrm{g}$ on an electronic balance. In order to determine the carbon content as a percentage of dry weight, 6 groups of 5 ctenophores (2 to $12 \mathrm{~mm}$ ) with empty guts were carefully rinsed in filtered water $(10 \% \mathrm{~S})$, placed on pre-ashed, pre-weighed GF/C filters, dried to constant weight at $60^{\circ} \mathrm{C}$ and weighed to the nearest $1 \mu \mathrm{g}$. The carbon content was measured using an elemental $\mathrm{C} / \mathrm{N}$ analyzer. These values for Mnemiopsis leidyi and conversions for Chrysaora quinquecirrha are given in Table 2 .

Digestion rates. The digestion times for Chrysaora quinquecirrha ephyrae feeding on rotifers Brachionus plicatilis and on ctenophore larvae Mnemiopsis leidyi were measured. Ephyrae were maintained in $500 \mathrm{ml}$ glass bowls for $12 \mathrm{~h}$ at ambient water temperature $\left(23\right.$ to $\left.24^{\circ} \mathrm{C}\right)$ in $20 \mu \mathrm{m}$ filtered estuary water $(12 \% \mathrm{~S})$ with Artemia salina nauplii as prey, so that their guts would empty of rotifer or ctenophore prey. $B$. plicatilis or $M$. leidyi were then added to the glass bowls with ephyrae. After a 15 min feeding period, each ephyra was carefully examined for prey. If prey were present, the ephyra was isolated in a small beaker with $20 \mu \mathrm{m}$ filtered estuary water $(12 \% \mathrm{~S})$ at $23^{\circ} \mathrm{C}$, and prey in the gut examined at $15 \mathrm{~min}$ intervals until prey could not be identified. The digestion times were averaged to give a digestion time of $C$. quinquecirrha ephyrae feeding on $B$. plicatilis and on $M$. leidyi (accuracy = $\pm 30 \mathrm{~min}$ ).

\section{RESULTS}

\section{Clearance rates of microplankton in monoculture}

The dinoflagellate Gymnodinium sanquineum was not eaten by ephyrae of Chrysaora quinquecirrha (Fig. 1A). The numbers of prey left in the experimental bottles (with ephyrae) compared with the control bottles (without ephyrae) were not significantly different at the end of incubation ( $p>0.05, t$-test). Moreover, no prey were found in the guts of ephyrae

In contrast, both ciliates Strobilidium sp. and rotifers Brachionus plicatilis were cleared by Chrysaora quinquecirrha ephyrae (Fig. 1B, C) $(p<0.001)$. Clearance on Strovilidium $\mathrm{sp}$. and $\bar{B}$. plicatilis was estimated to be 4 and $1 \mathrm{ml} \mathrm{h}^{-1}$ ind. ${ }^{-1}$, respectively. The feeding rates on rotifers were calculated by 2 different methods: (i) according to Eq. (1), and (ii) from the average gut contents of ephyrae by the end of incubation $\left(10 \pm 5\right.$ rotifers ephyrae $\left.{ }^{-1}\right)$ and the digestion time of the prey $(5.2 \mathrm{~h}$, Table 3$)$. By using method (i), it was found that each ephyra had removed an average of 15 rotifers during $8 \mathrm{~h}$ incubation. This value is close to the value of 11 obtained when using method (ii). Gut contents were not examined with Strobilidium sp. as prey.

Clearance rates of copepod nauplii by Chrysaora quinquecirrha ephyrae were low $\left(0.55 \mathrm{ml} \mathrm{h}^{-1}\right.$ ind. $\left.^{-1}\right)$ (Fig. 1D). However, after 24 h of incubation, the experimental bottles contained significantly fewer copepod nauplii than the control bottles without ephyrae ( $\mathrm{p}<$ $0.005)$. Based on the differences between control and experimental bottles, the feeding rate was 2.3 nauplii ingested ephyrae $e^{-1} d^{-1}$. This compares well with the value of 2.0 nauplii ingested ephyrae $\mathrm{e}^{-1} \mathrm{~d}^{-1}$ calculated from the average gut content of $0.3 \pm 0.5$ nauplii ephyrae $^{-1}$.

Ephyrae of Chrysaora quinquecirrha also fed on larvae of the ctenophore Mnemiopsis leidyi (Fig. 1E). The numbers of prey remaining in experimental and

Table 3. Chrysaora quinquecirrha. Digestion time (h) for ephyrae fed on ctenophore Mnemiopsis leidyi and rotifer Brachionus plicatilis. $\mathrm{n}=$ number of prey followed

\begin{tabular}{|lcccc|}
\hline Prey & $\begin{array}{c}\text { Size of } \\
\text { ephyrae }(\mathrm{mm})\end{array}$ & $\begin{array}{c}\text { Size of } \\
\text { prey (mm) }\end{array}$ & $\begin{array}{c}\text { Digestion } \\
\text { time }\end{array}$ & $n$ \\
\hline $\begin{array}{l}\text { B. plicatilis } \\
\text { M. leidyi }\end{array}$ & $3.1 \pm 1.2$ & 0.2 & $5.28 \pm 2.48$ & 21 \\
& $2.8 \pm 0.7$ & $1.5 \pm 0.3$ & $2.22 \pm 0.72$ & 10 \\
\hline
\end{tabular}



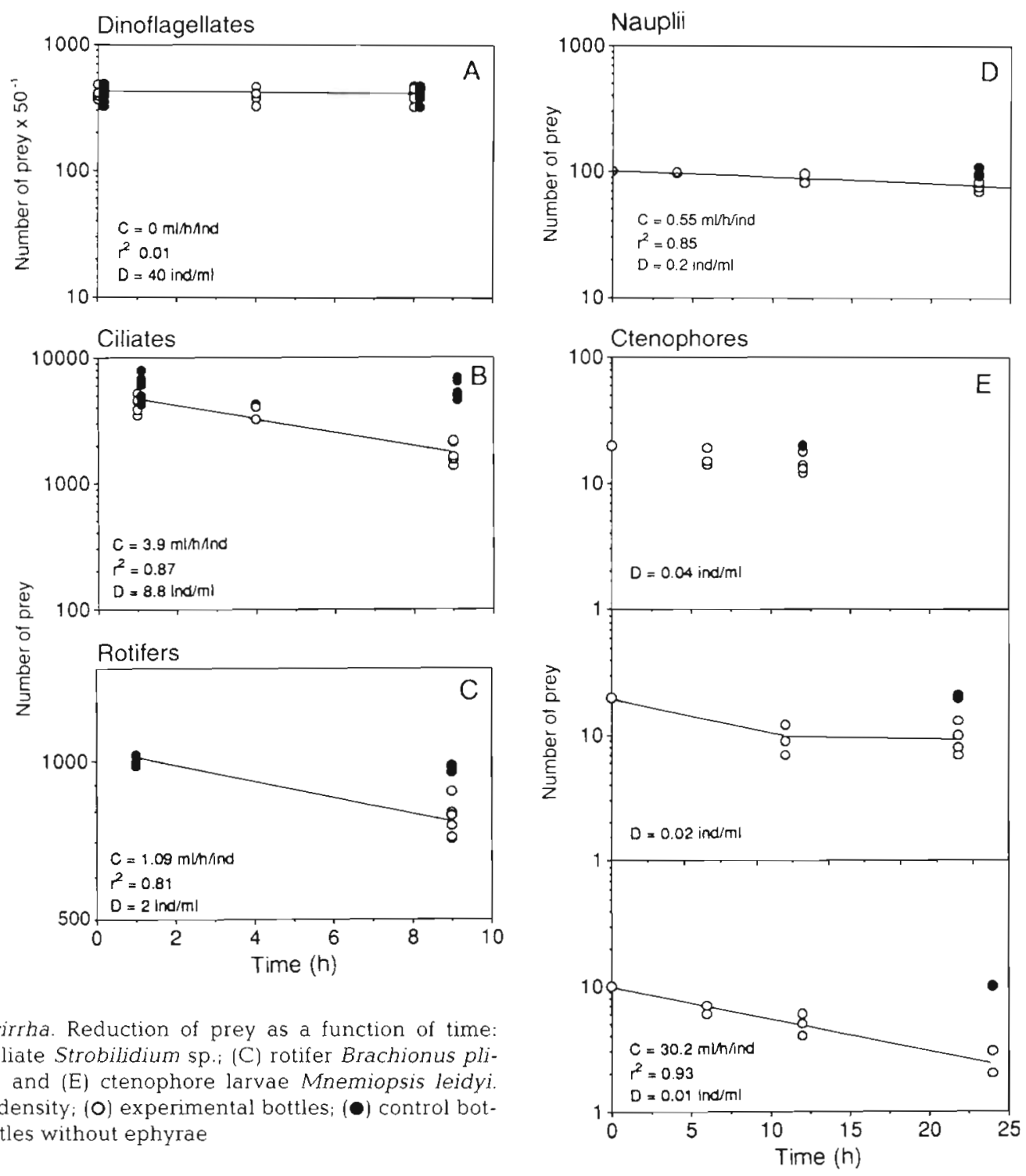

Fig. 1. Chrysaora quinquecirrha. Reduction of prey as a function of time: (A) Gymnodinium sp.; (B) ciliate Strobilidium sp.; (C) rotifer Brachionus plicatilis; (D) copepod nauplii; and (E) ctenophore larvae Mnemiopsis leidyi. $C$ : clearance: $D$ : initial prey density; (O) experimental bottles; $(\bullet)$ control bottles without ephyrae

control bottles were significantly different in all 3 experiments $(\mathrm{p}<0.001$ ). The ephyrae could ingest ctenophores one-half their own size (Table 1). If the ctenophore was too large to enter the gut, it was digested in the oral lips or even outside the ephyrae. Feeding by the ephyrae was saturated when the initial prey concentration was 0.04 and 0.02 ind. $\mathrm{ml}^{-1}$, but no saturation was observed at 0.01 ind. $\mathrm{ml}^{-1}$. At that prey density clearance was $30 \mathrm{ml} \mathrm{h}^{-1}$ ephyra $^{-1}$ (Fig. 1E).

\section{Clearance on mixed zooplankton}

The number of prey in natural zooplankton assemblages decreased in all incubation bottles over $24 \mathrm{~h}$, including the controls without ephyrae (Table 4). However, the decrease in prey organisms was more pronounced in the bottles with ephyrae than in control bottles without ephyrae, except for ciliates. The difference between the number of prey in grazed bottles and the number in control bottles at $t=24 \mathrm{~h}$ was interpreted as removal due to predation by ephyrae. Significant grazing by ephyrae was observed on rotifers Synchaeta sp. ( $p<0.01, t$-test), copepod nauplii, and loricate ciliates (tintinnids) ( $p<0.02$ ), but grazing was not detected on aloricate ciliates. Clearance was estimated to be $1.3 \mathrm{ml} \mathrm{h}^{-1}$ ind.-1 on rotifers and $0.3 \mathrm{ml} \mathrm{h}^{-1}$ ind.$^{-1}$ on nauplii and tintinnids. Rotifers were the predominant prey type in yui cunteñts of ephyrae at $12 \mathrm{~h}$, but all 4 prey types were found in the guts (Table 4). 
Table 4. Chrysaora quinquecirsha. Removal of prey from natural zooplankton assamblages by ephyrae. Eight control bottles were incubated ( 4 were stopped at $t=0$ and 4 at $t=24$ ). Six experimental bottles were incubated and stopped at $t=24$. Prey densities and total number of prey are means + SD. Differences in average prey densities between control and grazed treatments at the end of each incubation are presented. Negative differences indicate removal of prey by ephyrae; difference significant at $\mathrm{p}<0.01($ (), at $\mathrm{p}<0.02(")$

\begin{tabular}{|c|c|c|c|c|c|c|c|}
\hline Prey & $\begin{array}{c}\text { Prey } \\
\text { density } \\
t=0 \\
\text { (no. prey } \mathrm{mL}^{-1} \text { ) }\end{array}$ & $\begin{array}{l}\text { Total no. } \\
\text { of prey } \\
t=0\end{array}$ & $\begin{array}{c}\text { Total no. } \\
\text { of prey } \\
t=24 \\
\text { (control) }\end{array}$ & $\begin{array}{c}\text { Total no. } \\
\text { of prey } \\
t=24 \\
(\exp t)\end{array}$ & $\begin{array}{c}\text { Difference, } \\
\text { no. of prey } \\
t=24 \\
\text { (control - expt) }\end{array}$ & $\begin{array}{c}\text { Clearance } \\
\left(\mathrm{ml} \mathrm{h}^{-1}\right. \\
\left.\text { ind }^{-1}\right)\end{array}$ & $\begin{array}{l}\text { Average no. of } \\
\text { prey in guts } \\
t=12\end{array}$ \\
\hline Synchaeta sp. & $4.53 \pm 0.58$ & $2263 \pm 291$ & $1506 \pm 177$ & $1075 \pm 147$ & $-431^{\circ}$ & 1.3 & $3.1 \pm 2.1$ \\
\hline Copepod nauplii & $0.64 \pm 0.26$ & $319 \pm 130$ & $259 \pm 30$ & $175 \pm 76$ & $-84 \cdots$ & 0.3 & $0.3 \pm 0.5$ \\
\hline Aloricate ciliates & $1.21 \pm 0.30$ & $606 \pm 149$ & $78 \pm 74$ & $153 \pm 71$ & +75 & - & $0.7 \pm 0.7$ \\
\hline Tintinnids & $2.54 \pm 0.45$ & $1272 \pm 224$ & $863 \pm 215$ & $588 \pm 163$ & $-275^{*}$ & 0.25 & $0.4 \pm 0.5$ \\
\hline
\end{tabular}

\section{Gut contents of ephyrae sampled in Chesapeake Bay}

Rotifers, aloricate riliates, tintinnids and copepod nauplii were found in gut contents of ephyrae collected in Chesapeake Bay (Table 5). Those prey, together with adult copepods, were the dominant prey items $(96 \%)$ found in ephyrae $4 \mathrm{~mm}$ in diameter. The high number of ciliates was due to the presence of 40 ciliates in 1 ephyra. No attempt was made to quantify phytoplankton, but the numbers were low.

\section{Growth experiment}

Ephyrae of Chrysaora quinquecirrha showed increasing growth rate as the number of rotifers Brachionus plicatilis available increased (Fig. 2A). A maximal growth rate $\left(\mu_{\max }\right)$ of $0.32 \mathrm{~d}^{-1}$ was obtained when about 375 rotifers $1^{-1}$ were added each day. and the growth rate did not increase further at higher prey levels. At the maximal growth rate, the mean diameter of ephyrae increased from $2.2 \mathrm{~mm}$ to $3.6 \mathrm{~mm}$ during the $4 \mathrm{~d}$ incubation, corresponding to an increase in mean dry weight from 0.02 to $0.08 \mathrm{mg}$ (Table 6).

When ctenophore larvae were used as prey, the growth rate also increased with increased prey level, and the $\mu_{\max }$ obtained was considerably higher. At

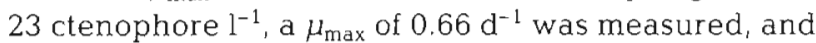
the mean diameter of ephyrae increased from 3.3 to $8.8 \mathrm{~mm}$, corresponding to an increase from 0.06 to $0.85 \mathrm{mg}$ dry weight (Table 6 ). When both rotifers and ctenophores were added, the growth pattern was similar to the experiment where ctenophores were added alone, and the maximal growth rate obtained was only slightly higher $\left(0.7 \mathrm{~d}^{-1}\right)$ (Fig. 2A).

Ingestion $(I)$ of rotifers increased linearly with prey concentration (Fig. 2B), regardless of the presence of
Table 5. Chrysaora quinquecirrha. Gut contents of 31 ephyrae collected from 21 May to 25 August at 4 stations in Chesapeake Bay. Average diameter of ephyrae was $3.8 \pm 2.9 \mathrm{~mm}$ and prey was found in $50 \%$ of the animals

\begin{tabular}{|lcl|}
\hline Prey type & No. of prey ephyrae & SD \\
\hline Aloricate ciliates & 1.43 & \pm 7.17 \\
Rotifers & 0.77 & \pm 1.77 \\
Copepods & 0.70 & \pm 2.56 \\
Tintinnids & 0.23 & \pm 0.50 \\
Copepod nauplii & 0.17 & \pm 0.45 \\
Fish larvae & 0.07 & \pm 0.36 \\
Polychaete larvae & 0.03 & \pm 0.18 \\
Bivalve veligers & 0.03 & \pm 0.18 \\
\end{tabular}

ctenophores in the incubation bottles. We did not calculate a relationship between ingestion of ctenophores and prey density because all ctenophores in most growth experiments were consumed.

Clearance on rotifers was constant with increasing prey level averaging about $22 \mathrm{ml} \mathrm{h}^{-1}$ ind.$^{-1}$, both when rotifers were added alone and when rotifers were added with ctenophore larvae (Fig. 2C) (slope of line, $b$ $=0, p=0.56$ ). When ctenophore larvae were added at low densities (with or without rotifers), all larvae were eaten by the end of $24 \mathrm{~h}$ incubation (Table 6). Therefore clearance could only be calculated at the highest prey concentration. Clearance rates on ctenophore larvae decreased from $55 \mathrm{ml} \mathrm{h}^{-1}$ ind $^{-1}$ at 3 prey $\mathrm{l}^{-1}$ to 20 $\mathrm{ml} \mathrm{h}^{-1}$ ind. ${ }^{-1}$ at 50 prey $\mathrm{l}^{-1}$ (Fig. 2C).

For ephyrae showing positive growth, the net growth efficiency (NGE) varied between 2 and $25 \%$ with the highest NGE at medium prey levels (Table 6). On average, NGE was lower with ctenophores alone $(4.9 \pm 1.8 \%)$ than in the experiment with both ctenophores and rotifers $(10.0 \pm 3.8 \%)$, or in the experiment with only rotifers offered as prey (13.6 \pm $8.4 \%)$ 


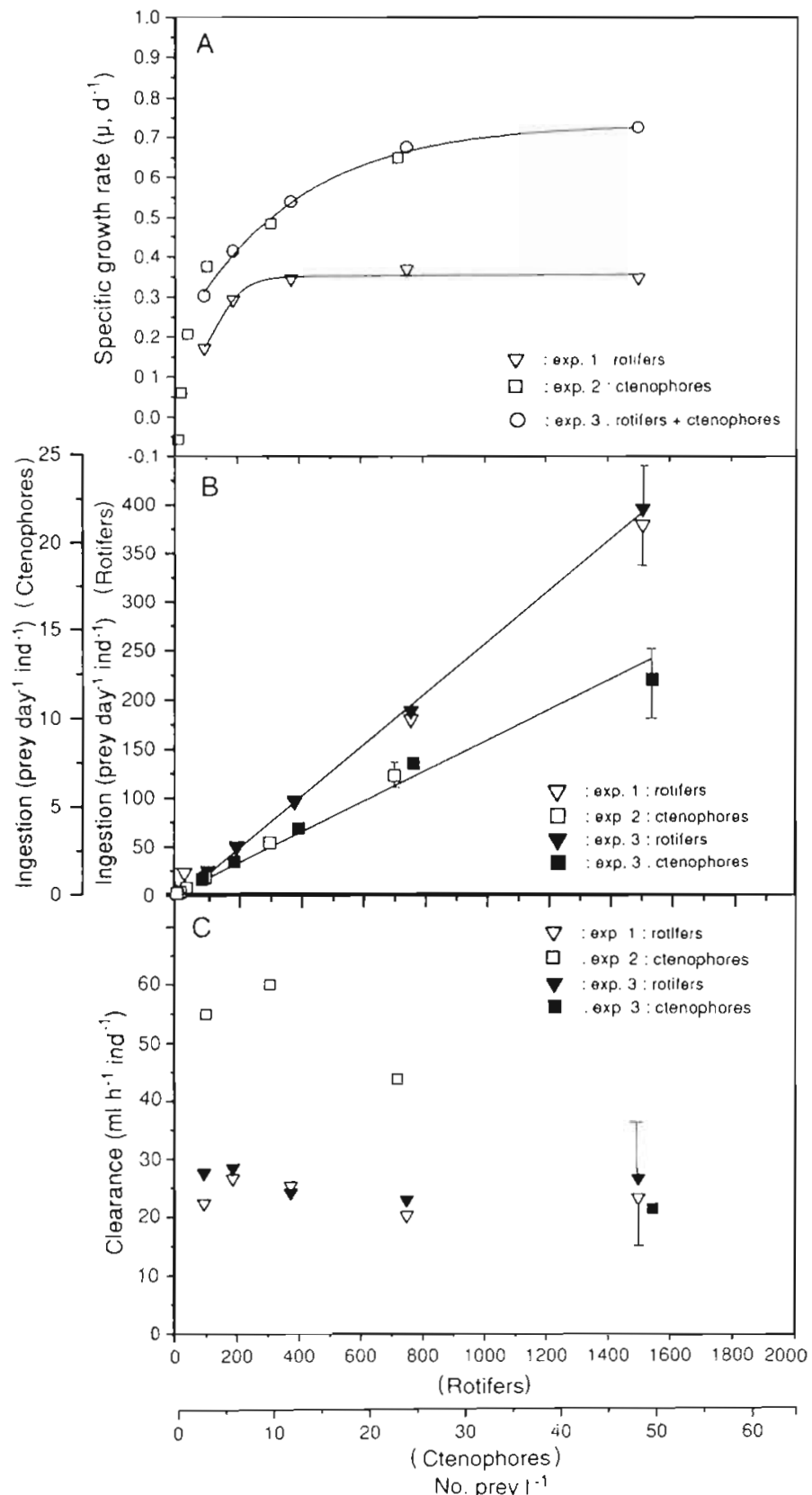

Fig. 2. Chrysaora quinquecirrha. Growth, ingestion and clearance of ephyrae during $4 \mathrm{~d}$ incubation with rotifers and ctenophore larvae offered in various densities. (A) Specific growth rate $(\mu)$ of ephyrae feeding on rotifer Brachionus plicatilis (Expt 1) (line drawn by eye), ctenophore larvae Mnemiopsis leidyi (Expł 2) and both B. plicatilis and M. leidyi (Expt 3) (line drawn by eye). The $\mu$ was calculated from the difference in dry weight of ephyrae at time 0 and time $96 \mathrm{~h}$ using Eq. (2). (B) Ingestion of rotifers B. plicatilis (Expts 1 and 3) and ingestion of ctenophore larvae $M$. Jeidyi (Expts 2 and 3 ) by ephyrae. Ingestion was calculated using Eq. (3). Representative SD is shown for a single data set. (C) Clearance of rotifers B. phcatuls (Expts i duci 3 j añu cleurance of ctenophore larvae $M$. leidyi (Expts 2 and 3). Clearance was calculated according to Eq. (1). Representative SD is shown for a single data set

\section{DISCUSSION}

\section{Clearance rates of microplankton in monoculture}

Adult medusae of Chrysaora quinquecirrha, which occur up to $18 \mathrm{~cm}$ in diameter in Chesapeake Bay, feed extensively on both copepods (Purcell 1992) and ctenophores (Miller 1974, Feigenbaum et al. 1982, Feigenbaum \& Kelly 1984), but it has been suggested that clearance rates might be higher on ctenophores than on copepods (Larson 1986). In this study, when small ephyrae ( $3 \mathrm{~mm}$ diameter) of $C$. quinquecirrha fed on larvae of the ctenophore Mnemiopsis leidyi (1.5 mm length), the clearance was much higher than on any other prey offered (Fig. 1). The relatively large size of ctenophore larvae might increase the predatorprey encounter rate and hence increase clearance on ctenophore larvae compared with the other prey types. Further, in contrast to copepod naupli and the ciliate Strobilidium sp. (Buskey et al. 1993), ctenophore larvae may lack an escape response. The results suggest that ctenophore larvae when abundant are a very important food source for ephyrae of C. quinquecirrha.

Clearance on copepod nauplii $\left(0.55 \mathrm{ml} \mathrm{h}^{-1}\right.$ ind..$\left.^{-1}\right)$ was $1 / 60$ of clearance on clenophore larvae $\left(30 \mathrm{ml} \mathrm{h}^{-1}\right.$ ind.-1). Copepod nauplii have vigorous escape responses (Buskey et al. 1993), which may explain in part the low clearance. Density of nauplii was 200 ind. $1^{-1}$. Although this is a high value, such numbers are occasionally found in nature (Roman et al. 1993). The low clearance obtained was not due to saturation, as an average of only 0.3 nauplii was found in the gut contents of the ephyrae at the end of the experiment.

The dinoflagellate Gymnodinium sanguineum was not cleared by Chrysaora quinquecirrha (Fig. 1A). This is in accordance with the generally accepted role of jellyfish as carnivores, and it is also in agreement with the results of Haven \& Morales-Almo (1973), who found very few phytoplankters in gut contents of ephyrae fed on concentrated water samples from Sara Creek, Chesapeake Bay, USA.

In contrast, the ciliate Strobilidium sp. was cleared by the ephyrae, but the clearance rates were low $(4 \mathrm{ml}$ $\mathrm{h}^{-1}$ ind. ${ }^{-1}$; Fig. 1B) compared to the clearance on ctenophores. The density of Strobilidium sp. used in this study ( 8.8 ind. $\mathrm{ml}^{-1}$ ) was similar to the average in situ density of ciliates ( 11 ind. $\mathrm{ml}^{-1}$ ) reported by Dolan \& Gallegos (1991) in the Rhode River tributary of Chesapeake Bay.

The rotifer Brachionus plicatilis was also cleared by ephyrae (1.7 $\mathrm{mm}$ diameter), but clearance rates were

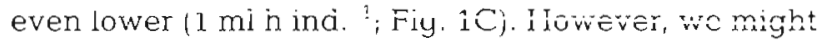
have underestimated clearance on rotifers as the density of $B$. plicatilis in our experiment ( 2 ind. $\left.\mathrm{ml}^{-1}\right)$ was 
Table 6. Chrysaora quinquecirrha. Production (P), ingestion (I) and net growth efficiency (NGE) of ephyrae feeding on: rotifer Brachionus plicatilis (Expt 1); ctenophore Mnemiopsis leidyi (Expt 2); or B. plicatilis $+M$. Leidyi. (Expt 3). Incubation period $=96 \mathrm{~h}$; $C_{0}=$ number of prey added each day of rotifer and ctenophore; $C_{24}=$ mean number $( \pm S D$ ) of prey left after each $24 \mathrm{~h}$ period of rotifer and ctenophore; $D_{\text {cten }}=$ mean length $\left( \pm S D\right.$ ) of ctenophore added; $D_{0}=$ initial mean $( \pm S D$ ) umbrella diameter of ephyrae; $D_{96}=$ mean $( \pm S D)$ umbrella diameter of ephyrae at time $96 \mathrm{~h} ; \mathrm{P}=$ individual production $(\mu \mathrm{g} C$ ) in ephyrae during the total incubation time; $I=$ individual ingestion ( $\mu \mathrm{g} C$ ) of rotifers or ctenophores by ephyrae during the total incubation time

\begin{tabular}{|c|c|c|c|c|c|c|c|c|c|}
\hline Expt no. & $\begin{array}{c}C_{0} \\
\text { Rotifer/cten }\end{array}$ & $\begin{array}{l}D_{\text {clen }} \\
(\mathrm{mm})\end{array}$ & $\begin{array}{c}C_{24} \\
\text { Rotifer/cten }\end{array}$ & $\begin{array}{c}D_{0} \\
(\mathrm{~mm})\end{array}$ & $\begin{array}{c}D_{96} \\
(\mathrm{~mm})\end{array}$ & $\begin{array}{c}P \\
\left(\mu g \mathrm{C} \text { ind. } .^{-1}\right)\end{array}$ & $\begin{array}{c}I \\
\left(\mu g \mathrm{C} \text { ind. }{ }^{-1}\right) \\
\text { Rotifer/cten }\end{array}$ & $\begin{array}{c}\text { Total } I \\
\left(\mu \mathrm{g} \mathrm{C} \text { ind } .^{-1}\right)\end{array}$ & $\begin{array}{l}\text { NGE } \\
(\%)\end{array}$ \\
\hline \multirow[t]{5}{*}{1} & $4500 / 0$ & - & $714 \pm 298 /$ & $2.9 \pm 0.8$ & $4.6 \pm 1.1$ & 13.3 & $227.2 /-$ & 227.2 & 6.5 \\
\hline & $2250 / 0$ & - & $451 \pm 201 /-$ & $2.1 \pm 0.6$ & $3.5 \pm 0.9$ & 6.3 & $107.9 /-$ & 107.9 & 6.5 \\
\hline & $1125 / 0$ & - & $149 \pm 66 /-$ & $2.2 \pm 0.7$ & $3.6 \pm 1.1$ & 6.7 & $58.6 /-$ & 58.6 & 12.8 \\
\hline & $563 / 0$ & - & $67 \pm 39 /-$ & $2.5 \pm 0.6$ & $3.8 \pm 0.9$ & 7.3 & $29.8 /-$ & 29.8 & 27.2 \\
\hline & $281 / 0$ & - & $47 \pm 28 /-$ & $2.6 \pm 0.7$ & $3.2 \pm 0.6$ & 2.8 & $14.0 /-$ & 14 & 22.5 \\
\hline \multirow[t]{6}{*}{2} & $0 / 70$ & $5.0 \pm 1.5$ & $-/ 2.1 \pm 3.5$ & $3.3 \pm 0.6$ & $8.0 \pm 1.3$ & 83.1 & $-/ 1986.1$ & 1986.1 & 4.6 \\
\hline & $0 / 30$ & $5.1 \pm 1.3$ & $-/ 0.3 \pm 0.5$ & $3.6 \pm 0.6$ & $7.1 \pm 1.3$ & 54.8 & -19030 & 903.9 & 6.7 \\
\hline & $0 / 10$ & $5.2 \pm 15$ & $-/ 0.1 \pm 0.3$ & $3.2 \pm 0.5$ & $5.4 \pm 1.5$ & 22.5 & $-/ 313.3$ & 313.3 & 8.0 \\
\hline & $0 / 4$ & $5.8 \pm 1.2$ & -10 & $3.1 \pm 0.4$ & $4.1 \pm 1.0$ & 7.2 & -157.5 & 157.5 & 5.1 \\
\hline & $0 / 2$ & $5.6 \pm 1.6$ & -10 & $3.1 \pm 0.5$ & $3.4 \pm 0.8$ & 18 & -173.4 & 73.4 & 2.7 \\
\hline & $0 / 1$ & $5.3 \pm 0.7$ & -10 & $3.4 \pm 0.5$ & $3.1 \pm 0.8$ & -1.8 & $-\quad 32.9$ & 32.9 & - \\
\hline \multirow[t]{5}{*}{3} & $4500 / 150$ & $2.5 \pm 0.71$ & $\begin{array}{c}544 \pm 435 / \\
27.3 \pm 22.5\end{array}$ & $2.2 \pm 0.5$ & $6.1 \pm 2.0$ & 38.8 & $237.4 / 894.5$ & 1131.8 & 3.8 \\
\hline & $2250 / 75$ & $2.4 \pm 0.55$ & $366 \pm 152 / 0$ & $3.0 \pm 0.8$ & $7.6 \pm 2.2$ & 72.3 & $113.0 / 503.8$ & 616.8 & 13.0 \\
\hline & $1125 / 38$ & $2.5 \pm 0.46$ & $165 \pm 79 / 0$ & $29 \pm 0.9$ & $6.1 \pm 1.8$ & 36.2 & $57.6 / 138.5$ & 334.6 & 12.0 \\
\hline & $563 / 19$ & $2.5 \pm 0.58$ & $58 \pm 33 / 0$ & $3.0 \pm 0.6$ & $5.3 \pm 1.2$ & 22.2 & $30.3 / 138.5$ & 168.8 & 14.5 \\
\hline & $281 / 9$ & $2.54 \pm 0.46$ & $31 \pm 9 \quad 10$ & $2.7 \pm 0.8$ & $4.1 \pm 1.9$ & 9.1 & $15 / 65.6$ & 80.6 & 12.5 \\
\hline
\end{tabular}

high compared with the average natural density of rotifers in Rhode River tributary $\left(0.7\right.$ ind. $\left.\mathrm{ml}^{-1}\right)$. For example, clearance by Aurelia aurita ephyrae decreased approximately $30 \%$ when density of $B$. plicatilis increased from 0.7 to 1.5 ind. $\mathrm{ml}^{-1}$ (Olesen et al. 1994). Mean clearance on rotifers in the growth experiment was $22 \mathrm{ml} \mathrm{h}$ ind ${ }^{-1}$ at 1.5 ind. $\mathrm{ml}^{-1}$ (Fig. 2C), but the ephyrae used were slightly bigger (2.9 to $4.6 \mathrm{~mm}$ diameter). We believe that the true clearance rates for a $2 \mathrm{~mm}$ ephyrae of $B$. plicatilis is in the range 1 to $22 \mathrm{ml}$ $\mathrm{h}^{-1}$ ind. $^{-1}$. In natural waters it is generally Synchaeta spp. which are dominant rather than Brachionus, and Synchaeta spp. might be captured at different rates.

However, the results suggest that both ciliates and rotifers may also play an important role as food sources for ephyrae of Chrysaora quinquecirrha.

It is well esablished that increased container volume tends to increase clearance (reviewed by Olesen 1995), and some of the differences between clearance rates obtained in monoculture experiments and clearance rates measured in growth experiments can also be explained from differences in container volume. In a $0.5 \mathrm{I}$ container Brachionus plicatilis was cleared at $1 \mathrm{ml} \mathrm{h}^{-1}$ ind $^{-1}$ by 1 to $7 \mathrm{~mm}$ diameter ephyrae (Fig. 1C), whereas the rate was $22 \mathrm{ml} \mathrm{h}^{-1}$ ind.$^{-1}$ in $3 \mathrm{l}$ containers by 2.9 to $4.6 \mathrm{~mm}$ diameter ephyrae (Fig. 2C, Table 6). Likewise, Mnemiopsis leidyi larvae was cleared at $30 \mathrm{ml} \mathrm{h}^{-1}$ ind. $^{-1}$ by $2.8 \mathrm{~mm}$ diameter ephyrae in $1 \mathrm{l}$ containers (Fig 1E), whereas the rate was $60 \mathrm{ml} \mathrm{h}^{-1}$ ind. ${ }^{-1}$ in $3 \mathrm{l}$ containers by 3.6 to $7.1 \mathrm{~mm}$. diameter ephyrae.

\section{Clearance on mixed zooplankton}

The clearance of rotifers Synchaeta sp. by ephyrae of Chrysaora quinquecirrha in mixed zooplankton culture was approximately the same $\left(1.3 \mathrm{ml} \mathrm{h}^{-1}\right.$ ind $\left.^{-1}\right)$ (Table 4) as clearance on monoculture of another rotifer, Brachionus plicatilis $\left(1.0 \mathrm{ml} \mathrm{h}^{-1}\right.$ ind..$^{-1}$ ) (Fig 1C). The decreasing number of rotifers in control bottles without ephyrae might be due to predation by the adult copepods, which were also present in the mixed zooplankton, as it is well established that copepods feed on rotifers (revlewed in Stoecker \& Capuzzo 1990, Gifford 1991).

The clearance of copepod nauplii by ephyrae in mixed zooplankton $\left(0.3 \mathrm{ml} \mathrm{\textrm {h } ^ { - 1 }}\right.$ ind. ${ }^{-1}$ ) (Table 4 ) also was similar to the rate obtained in monocultures $10.5 \mathrm{ml} \mathrm{h}^{-1}$ ind. $^{-1}$ ) (Fig. 1D). The decreased number of nauplii in control bottles without ephyrae were not statistically significant ( $p>0.05, t$-test), but some consumption by adult copepods may have occurred

Aloricate ciliates were also eaten by ephyrae in mixed zooplankton as they were identified in the gut contents of ephyrae at the end of incubation. However, 
even though ciliates were eaten by ephyrae, the numbers were higher in bottles with ephyrae than in those without ephyrae by the end of incubation (Table 4). Both copepods (Stoecker \& Egloff 1987, Stoecker \& Capuzzo 1990, Gifford 1991) and rotifers (Pourriot 1977, Stoecker \& Capuzzo 1990, Gifford 1991) are known to feed on aloricate ciliates and it is possible that total predation pressure on ciliates were lower in the bottles with ephyrae compared with the control bottles as the density of rotifers and copepods was reduced due to predation by the ephyrae. Moreover, food conditions for the ciliates may have been improved in the experimental bottles as predation by ephyrae on rotifers and copepods may have led to reduced grazing on phytoplankton and bacteria.

Tintinnids were also eaten by ephyrae of Chrysaora quinquecirrha although clearance was low $0.3 \mathrm{ml} \mathrm{h}^{-1}$ ind.$^{-1}$ ). The low clearance on tintinnids (Table 4), which are loricate ciliates, and the relatively high clearance on the aloricate ciliate Strobilidium sp. (Fig. 1D) are in agreement with the findings of Stoecker et al. (1987) for ephyrae of Aurelia aurita. Whereas microzooplankton may be important as a food source for ephyrae, $C$. quinqueciruha clearance rates obtained in this study were in general low, and it seems unlikely that ephyrae has any significant impact on microzooplankton populations in situ.

\section{Gut contents of ephyrae sampled in Chesapeake Bay}

The gut contents given in Table 5 should be considered as minimum estimates, as some material might have been lost during net collection of the ephyrae. However, the relatively high numbers of ciliates and rotifers found in the guts are in agreement with the results of Haven \& Morales-Almo (1973). They found that protozoa were the most frequently found components in the gut of ephyrae collected from May to June in Sarah Creek, Chesapeake Bay. Further, when ephyrae were fed in the laboratory on concentrated water samples, it was demonstrated that rotifers were ingested with higher efficiency than for any other microplankton component. Thus, the gut content analysis present in this study and others support the idea of ciliates and rotifers as significant food sources for ephyrae of Chrysaora quinquecirrha.

\section{Growth of ephyrae}

Several species of scyphomedusae and hydromedusae are known to eat other species of gelatinous competitors and intraguild predation may confer several advantages (reviewed by Purcell 1991). In this

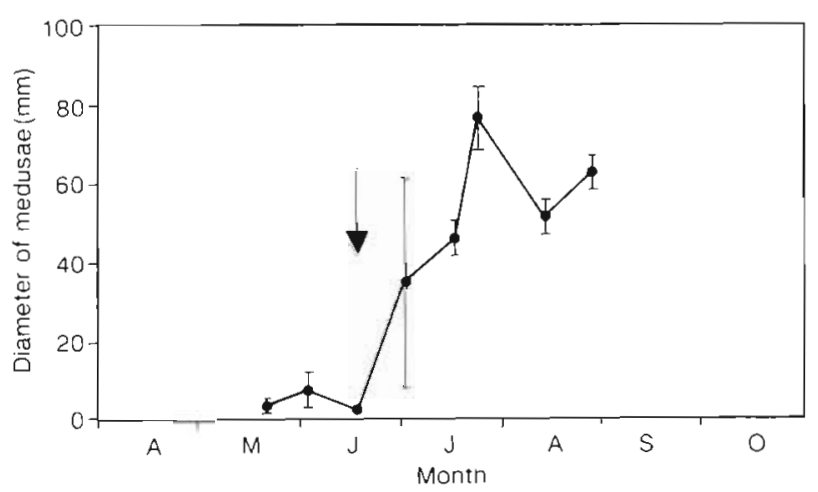

Fig. 3. Chrysaora quinquecirrha. Growth of medusae collected in the Tred Avon River tributary of Chesapeake Bay (USA), during 1993. Standard error is shown. Arrow indicates the onset of a ctenophore bloom

study, we found that growth rates of Chrysaora quinquecirrha ephyrae in the laboratory were greatest with Mnemiopsis leidyi larvae as prey, and it is likely that $M$. leidyi is critically important for the growth of $C$. quinquecirrha also in situ. Following the onset of a ctenophore bloom, the mean diameter of $C$. quinquecirrha in the Tred Avon River increased dramatically (Fig. 3), and the same maximal growth rate $\left(0.6 \mathrm{~d}^{-1}\right)$ was found in situ as in the laboratory experiments with ctenophore larvae as prey. This growth rate is, to our knowledge, the highest ever reported for any scyphomedusan species. Earlier laboratory growth studies on ephyrae showed lower growth rates than rates observed in situ. Ephyrae fed newly hatched Artemia salina larvae and other small organisms lived less than $7 \mathrm{~d}$, and small medusae $(8.8 \mathrm{~mm})$ grew at only $0.11 \mathrm{~d}^{-1}$ when fed polychaetous annelids (Cargo \& Schultz 1966). Ephyrae fed strained ctenophares lived for $49 \mathrm{~d}$, but the growth rate was only $0.28 \mathrm{~d}^{-1}$ compared to a rate of $0.39 \mathrm{~d}^{-1}$ in St. John Creek, Chesapeake Bay, USA (Cargo \& Schultz 1967). Larson (1986) obtained a biomass doubling in $6 \mathrm{~d}$ for one $C$. quinquecirrha medusa (65 mm diameter) (fed pieces of Cassiopea frondosa medusae), corresponding to an instantaneous specific growth rate of $0.1 \mathrm{~d}^{-1}$. In the present study, ephyrae (3.3 $\mathrm{mm}$ diameter) increased their biomass (dry weight) by a factor of 13 in only $4 \mathrm{~d}$ corresponding to a growth rate of $0.6 \mathrm{~d}^{-1}$, when live ctenophore larvae were offered in excess. In contrast, when ephyrae $(2.9$ $\mathrm{mm}$ ) were fed the rotifer Brachionus plicatilis, the maximal growth rate was only $0.32 \mathrm{~d}^{-1}$ (Fig. 2A). That is similar to the value of $0.22 \mathrm{~d}^{-1}$ obtained by Olesen et al. (1994) for Aurelia aurita ephyrae (4 mm diameter) with $B$. plicatilis as prey. In situ populations of scyphomedusae usually show growth rates in the range of 0.1 to $0.4 \mathrm{~d}^{-i}$ (C: quinquecirrind: Calyu \& Suliuitz 1967, A. anrita: Moller 1980, Hernroth \& Groendahl 1983, Van der Veer \& Oorthuysen 1985; Cyanea sp.: Brewer 1989). 
The digestion time for Mnemiopsis leidyi larvae was less than half the digestion time for Brachionus plicatilis (Table 6), and this may contribute to the relative high growth rate of ephyrae feeding on $M$. leidyi. However, it is surprising that NGE for ephyrae feeding on ctenophores only averaged 5\%. Larson (1986) found an NGE of approximately $11 \%$ for a $65 \mathrm{~mm}$ medusae of Chrysaora quinquecirrha feeding on another medusa, Cassiopea frondosa (assuming an assimilation efficiency of $90 \%$; Purcell 1983). However, we believe that NGE in both studies may have been underestimated due to superfluous feeding. Reeve et al. (1989) found that the ctenophore M. mccradyi continued to feed at high food concentrations, displacing partially digested material. Therefore, NGE calculated as production/ingestion decreased at high food concentration due to reduced assimilation efficiency. In the present study NGE was calculated from ingestion by assuming a constant assimilation efficiency of $90 \%$ regardless of food concentration and thus, the low NGE at high food concentration may be due to an overestimation of the assimilation efficiency. Ctenophores had diameters nearly as large as the ephyrae, and could not be completely ingested upon capture. Therefore, part of digestion occurred before complete ingestion, and some ctenophore tissue could have been lost.

Clearance by Chrysaora quinquecirrha ephyrae appeared constant with increasing concentrations of rotifers in the present study, and as consequence a positive and linear relationship between food concentration and ingestion was observed (Fig, 2B, C). There was no sign of saturation of ephyrae even at the highest prey concentration (clearance remained at the same level). A similar linear relationship between food concentration and feeding rate for C. quinquecirrha medusae has previously been reported in field studies with copepods and ichthyoplankton as prey (Purcell $1992,1994 \mathrm{~b})$. These results demonstrate a high predation potential of $C$. quinquecirrha, even at high zooplankton densities. Linear relationships between prey density and feeding rate are generally observed for gelatinous predators, for example the hydromedusan Nemopsis bachei (Purcell \& Nemazic 1992), the scyphomedusan Aurelia aurita (Olesen et al. 1994) and the ctenophore Mnemiopsis mccradyi (Reeve et al. 1989). Feeding by ephyrae of $C$. quinquecirrha was saturated at 20 ctenophore larvae $\mathrm{I}^{-1}$ but not at 10 ind. $\mathrm{I}^{-1}$ (Figs. 1E \& 2C). However, maximum abundance of $M$. leidyi larvae in natural populations is usually below 1 ind. $\mathrm{I}^{-1}$ (Olney \& Houde 1993). Therefore, saturation of ephyrae by $M$. leidyi larvae in situ is unlikely.

Larvae of the ctenophore Mnemiopsis leidyi may be very important prey for ephyrae of Chrysaora quinquecirrha, as clearance on this species was several times higher than on any other zooplankton organisms tested in the laboratory. Larvae of $M$. leidyi were easily caught by newly budded ephyrae, even if the larvae were about the same size as the ephyrae, and the digestion time of ctenophore larvae was less than half the digestion time of rotifers, on which ephyrae also feed. Moreover, the maximum growth rate for ephyrae of $C$. quinquecirrha feeding on ctenophores was the highest rate reported for any scyphomedusae, and exceeded the rate obtained when rotifers were offered as prey by more than a factor of 2 . Clearance rates of adult medusae feeding on ctenophores $>2 \mathrm{~cm}$ long are also high (Miller 1974, Purcell \& Cowan 1995) and Purcell (1992) calculates that ctenophores could contribute more nitrogen to the diet than crustacean zooplankton. Predation by $C$. quinquecirrha medusae can reduce ctenophore population to zero in tributaries of Chesapeake Bay (Purcell et al. 1991). Therefore, we sugyest that the high growth rates of $C$. quinquecirrha in natural populations may be possible due to the abundance of $M$. leidyi in Chesapeake Bay.

Acknowledgements. We thank D. A. Nemazie and D. Gustafson for their valuable assistance. The research was funded by NSF grant OCE-9019404 to J.E.P. and by the Danish Research Academy. This is UMCEES contribution No. 2759.

\section{LITERATURE CITED}

Baird D, Ulanowicz RE (1989) The seasonal dynamics of the Chesapeake Bay ecosystem. Ecol Monogr 59(4):329-364

Bockstahler KR, Coats DW (1993) Spatial and temporal aspects of mixotrophy in Chesapeake Bay dinoflagellates. J Eukaryot Microbiol 40:49-60

Brewer RH (1989) The annual patterns of feeding, growth and sexual reproduction in Cyanea (Cnidaria: Syphozoa) in the Niantic River Estuary, Connecticut. Biol Bull 176: $272-281$

Buskey EJ, Couttler C, Strom S (1993) Locomotory patterns of microzooplankton: potential effects on food selectivity of larval fish. Bull Mar Sci 53:29-43

Cargo DG, King DR (1990; Forcasting the abundance of the sea nettle, Chrysaora quinquecirrha, in the Chesapeake Bay. Estuaries 13:486-491

Cargo DG, Rabenold GE (1980) Observations on the asexual reproduction activities of the sessile stage of the sea nettle Chrysara quinquecirrha (Scyphozoa). Estuaries 3:20-27

Cargo DG. Schultz LP (1966) Notes on the biology of the sea nettle Chrysaora quinquecirrha, in Chesapeake Bay Chesapeake Sci 7:95-100

Cargo DG, Schultz LP (1967) Further observations on the biology of the sea nettle and jellyfishes in Chesapeake Bay. Chesapeake Sci 8:209-220

Clifford HC, Cargo DG (1978) Feeding rates of the sea nettle, Chrysaora quinquecirrha, under laboratory conditions. Estuaries 1.:58-61

Cones HN Jr (1969) Strobulation of Chrysaora quinquecirrha polyps in the laboratory. Va J Sci 20:16-18

Dolan JR, Gallegos CL (1991) Trophic coupling of rotifers, microflagellates, and bacteria during fall months in the Rhode River Estuary. Mar Ecol Prog Ser 77:147-156 
Feigenbaum DL, Kelly M (1984) Changes in the lower Chesapeake Bay food chain in the presence of the sea nettle Chrysaora quinquecirrha (Scyphomedusa). Mar Ecol Prog Ser 19:39-47

Feigenbaum DL, Knowles D, Kelly M (1982) Trophic interactions of the sea nettle, Chrysaora quinquecirrha. Technical Report 82-2. Old Dominion University, Department of Oceanography, Norfolk, VA, p 1-16

Gifford DJ (1991) The protozoa-metazoan trophic link in pelagic ecosystems. J Protozool 38:81-86

Guillard RRL (1975) Culture of marine phytoplankton for feeding marine invertebrates. In: Smith WL, Chanley $\mathrm{MH}$ (eds) Culture of marine invertebrate animals. Plenum Press, New York, p 29-60

Hasle GR (1978) The inverted microscope method. In: Sournia A (ed) Phytoplankton manual. UNESCO, Paris, p 88-96

Haven DS, Morales-Almo R (1973) Contents of the gastrovascular cavity of ephyrae and young medusae of the sea nettle Chrysaora quinquecirrha in a tributary of the York River, Viginia. In: Zubkoff $P$ (ed) Control measures for Chesapeake Bay jellyfish. Annual Reports for NMFS Contract N-043-226-72(G), Virginia Institute for Marine Science, Gloucester Point, VA, p 22-52

Hernroth L, Groendahl F (1983) On the biology of Aurelia aurita (L.). 1 Release and growth of Aurelia aurita (L.) ephyrae in the Gullmar Fjord, western Sweden, 19821983. Ophelia 22:189-199

Larson RJ (1986) The feeding and growth of the sea nettle, Chrysaora quinquecirrha (Desor), in the laboratory. Estuaries 9:376-379

Loeb MJ (1972) Strobilation in the Chesapeake Bay sea nettle Chrysaora quinquecirrha. 1. The effects of environmental temperature changes on strobilation and growth. $J$ Exp Zool 180:279-292

Loeb MJ, Blanquet RS (1973) Feeding behavior in polyps of the Chesapeake Bay sea nettle, Chrysaora quinquecirrha (Desor, 1848). Biol Bull Mar Biol Lab Woods Hole 145: $150-158$

Mayer AG (1910) Medusae of the world, Vol III. The Scyphomedusae. Publ No 109, Carnegie Inst, Washington, DC, p 585-588

Miller RJ (1974) Distribution and biomass of an estuarine ctenophore population, Mnemiopsis leidyi. Cheseapeake Sci $15: 1-8$

Moller H (1980) Population dynamics of Aurelia aurita medusae in Kiel Bight, Germany (FRG). Mar Biol 60:123-128

Olesen NJ (1995) Clearance potential of jellyfish Aurelia aurita, and predation impact on zooplankton in a shallow cove. Mar Ecol Prog Ser 124:63-72

Olesen NJ, Frandsen K, Riisgård HU (1994) Population dynamics, growth and energetics of jellyfish Aurelia aurita in a shallow fjord. Mar Ecol Prog Ser 105:9-18

Olney JE, Houde ED (1993) Evaluation of in situ silhouette photography in investigations of estuarine zooplankton

This article was submitted to the editor and ichthyoplankton. Bull Mar Sci 52:845-872

Pourriot R (1977) Food and feeding habits of Rotifera. Arch Hydrobiol Beih Ergeb Limnol 8:243-260

Purcell JE (1983) Digestion rates and assimilation efficiencies of siphonophores fed zooplankton prey. Mar Biol 73: $257-261$

Purcell JE (1991) A review of cnidarians and ctenophores feeding on competitors in the plankton. Hydrobiologia 216/217:335-342

Purcell JE (1992) Effects of predation by the scyphomedusan Chrysaora quinquecirrha on zooplankton populations in Chesapeake Bay, USA Mar Ecol Prog Ser 87:65-76

Purcell JE, Cowan JH Jr (1995) Predation by the scyphomedusan Chrysaora quinquecirrha on Mnemiopsis leidyi ctenophores. Mar Ecol Prog Ser 128:63-70

Purcell JE, Cresswell FP, Cargo DG, Kennedy VS (1991) Differential ingestion and digestion of bivalve larvae by the scyphozoan Chrysaora quinquecirrha and by the ctenophore Mnemiopsis leidyi. Biol Bull 180:103-111

Purcell JE, Nemazie DA (1992) Quantitative feeding ecology of the hydromedusan Nemopsis bachei in Chesapeake Bay. Mar Biol 113:305-311

Purcell JE, Nemazie DA, Dorsey SE, Houde ED, Gamble JC (1994a) Predation mortality of bay anchovy (Anchoa mitchilli) eggs and larvae due to scyphomedusae and ctenophores in Chesapeake Bay. Mar Ecol Prog Ser $114: 47-58$

Purcell JE, White JR, Roman MR (1994b) Predation by gelatinous zooplankton and resource limitation as potential controls of Acartia tonsa copepod populations in Chesapeake Bay. Limnol Oceanogr 39:263-278

Reeve MR, Syms MA, Kremer P (1989) Growth dynamics of a ctenophore (Mnemiopsis) in relation to variable food supply. 1. Carbon biomass, feeding, egg production, growth and assimilation efficiency. J Plankton Res 11 : $535-552$

Roman MR, Gauzens AL, Rhinehart WK, White JR (1993) Effects of low oxygen waters on Chesapeake Bay zooplankton. Limnol Oceanogr 38:1603-1614

Stoecker DK, Capuzzo JM (1990) Predation on protozoa: its importance to zooplankton. J Plankton Res 12:891-908

Stoecker DK, Egloff DA (1987) Predation by Acartia tonsa Dana on planktonic ciliates and rotifers. J Exp Mar Biol Ecol 110:53-68

Stoecker DK, Michaels AE, Davies LH (1987) Grazing by the jellyfish, Aurelia aurita, on microzooplankton. J Plankton Res 9:901-915

Szyper JP (1989) Nutritional depletion of the aquaculture feed organisms Euterpina acutifrons, Artemia sp. and Brachionus plicatilis during starvation. J World Aquacult Soc 20: $162-169$

Van der Veer HW, Oorthuysen W (1985) Abundance, growth and food demand of the scyphomedusa Aurelia aurita in the Western Wadden Sea. Neth J Sea Res 19(1):38-44

Manuscript first received: March 14, 1995

Revised version accepted: February 26, 1996 